\title{
Rectification of the register - prospective or retrospective?
}

\author{
Emma Lees*
}

Keywords: Land Registration Act 2002, rectification, priorities

Abstract: In Gold Harp v MacLeod [2014] EWCA Civ 1084, the Court of Appeal considers Schedule 4, paragraph 8 Land Registration Act 2002. It interprets this provision so as to mean that the priority between mistakenly de-registered interests and registered interests can be altered following rectification. The court can give the de-registered interest the priority which it 'would have had' but for the mistake. In other words, it allows for retrospective rectification. This case note concludes that this is the correct interpretation of paragraph 8 and of the words 'for the future'. However, it argues that the current range of options available to the court in terms of rectification are producing uncertainty, and that a better approach may be to rely on the priority provisions in sections 28 and 29 .

In Gold Harp v MacLeod, ${ }^{1}$ the courts have once again been called upon to consider the statutory provisions contained in Schedule 4 of the Land Registration Act 2002 (Sch 4, LRA 2002) and rectification of the register. Unfortunately, although the Court of Appeal gives a clear answer to the specific question before it, the piecemeal approach to the interpretation of Sch 4 continues.

Schedule 4 LRA 2002 controls the registrar and court's ability to alter the register. Paragraph 2 stipulates the conditions under which such alteration can be made, including rectification to correct a mistake. The central provision in this case however was paragraph 8 of Sch 4 . The paragraph stipulates that: '[t]he powers under this Schedule to alter the register, so far as relating to rectification, extend to changing for the future the priority of any interest affecting the registered estate or charge concerned'.

There were two possible interpretations of this provision. Firstly, it could be interpreted as providing for a power to rectify the register in such a way as to alter the priority of interests so as to reflect how they would have been had no mistake been made. ${ }^{2}$ Secondly, it could be interpreted so as to mean that no such change to priorities could take place, with changes to priority being 'for the future' only. ${ }^{3}$ Thus the re-registered interest would affect the estate only after that point, and could only take priority over interests created after that date. ${ }^{4}$ The court adopts the first interpretation. This is a natural interpretation of the statutory language. However, what the court fails to examine, is how this interpretation interacts with the other provisions of the 2002 Act as previously interpreted.

It will be argued here that whilst Gold Harp provides a good practical solution to the specific problem of priority following rectification, it produces an inconsistency when

\footnotetext{
Lecturer in Property and Environmental Law, Department of Land Economy, University of Cambridge

${ }^{1}$ Gold Harp Properties v McLeod \& Others [2014] EWCA Civ 1084

${ }^{2}$ ibid at [97]

${ }^{3}$ ibid at $[94]$

${ }^{4}$ ibid at [94]
} 
compared with the earlier interpretative decisions of the system of rectification as whole. This inconsistency undermines the reliability of the registration system. An alternative approach, which relies on the priority provisions in sections 28 and 29 LRA 2002, is then explored.

\section{Facts}

The case involved a leasehold estate relating to a property in Kensington. The top floor (the 'roofspace') had not been converted to residential accommodation. The claimants each acquired a leasehold estate in the roofspace - half each - under 135year leases. Leases to the ground and first floor flats were acquired by $\mathrm{Mr} \mathrm{Ralph} . \mathrm{Mr}$ Ralph planned to acquire the leases to the roofspace with a view to development.

In order to achieve this, Mr Ralph senior encouraged his son, Matthew, to acquire freehold title to the property, which he duly did. Ground rent for the roofspace was then not paid on time by the claimants, and so a firm of bailiffs were instructed to proceed to formal re-entry. This was not a lawful re-entry under the terms of the lease. Despite this, an application was made to the Land Registry to close the leasehold titles on the basis of a letter from the bailiffs as to the date of re-entry. The application was granted, and the register altered on $5^{\text {th }}$ August 2009. The fact that the re-entry was unlawful meant that no forfeiture had taken place and that the Registry ought not to have closed the leasehold titles as a result. The removal of the claimants' leases from the register was a mistake.

In the meantime, Matthew Ralph had granted a long lease of the whole roofspace to Insignia Property Ltd, a company controlled by a business associate of Mr Ralph senior. This was duly registered. This lease was then assigned to Lavender Estates Ltd and, on the same day, to Gold Harp Properties. Both Lavender and Gold Harp were owned and controlled by Mr Ralph. Gold Harp's lease was duly registered.

The claimants argued, firstly, that there had been no forfeiture. This was accepted by the judge at first instance. Thus the claimants applied to rectify the register. The judge held that the register should indeed be rectified. He held that the leases of the claimants should be entered on the register so as to have priority over the lease of Gold Harp. The Gold Harp lease would therefore become reversionary only. Gold Harp relied on two grounds in bringing their appeal. Firstly, they argued that the court should not have exercised the discretion accorded to it in Sch 4 to amend the register on the grounds that there were 'exceptional circumstances'. In other words, they argued that the presumption in favour of rectification, where an affected proprietor is not in possession, established in para 3(3) of Sch 4, was rebutted. Secondly, they argued that even if the register could have been rectified, the leases belonging to the claimants should rank after Gold Harp's lease as a matter of priority.

\section{Decision and reasoning}

Dealing with the second issue first, the court held that the register should be rectified in such a way as to rank Gold Harp's lease after the claimants' leases. ${ }^{5}$ It was clear in the case that the removal of the claimants' leases was a mistake: the critical question

\footnotetext{
${ }^{5}$ ibid at [91]
} 
was the steps that could be taken in order to correct this mistake. The court's response was based, primarily, on the wording of paragraph 8 of sch 4, LRA 2002. The court held that it conferred a power to give the claimants' leases priority. ${ }^{6}$ The removal of the leases from the register constituted a mistake, giving the court the power to rectify the register (para 2(1)(a), Sch 4). Although, according to Underhill LJ, para 8 limited the court's power to rectify the register as far as priorities were concerned, this did not prevent the court rectifying the register in such a way that Gold Harp would rank after the claimants. Underhill LJ concluded that the power to correct a mistake in para 2(1)(a) was qualified by the provision in para 8 so that such a correction, as related to priorities, could relate to priorities for the future only. Thus, the central question on his approach was what was meant by correction 'for the future'.

He determined that it meant that the court had the power to give the claimants' lease priority over Gold Harp, but that the consequences of this would be operative going forwards only. Gold Harp would not, for example, have been violating the claimants' prior right to possession if they had gone into possession prior to rectification. In reaching this conclusion, the court placed some reliance on the case law relating to section 82(2) Land Registration Act $1925 .{ }^{7}$ Underhill LJ held that it had been authoritatively established that section 82(2) gave the court the power to remove from the register a derivative interest created by a person who was registered proprietor at the time of the creation, albeit mistakenly (Argyle Building Society $\left.{ }^{8}\right){ }^{9}$ The court then concluded (from consideration of the Law Commission reports) that no substantive change was intended by the (quite substantial) change in wording represented by the 2002 Act. $^{10}$

The judge also relied on the decision of the Deputy Adjudicator in Knights Construction $v$ Roberto Mac. ${ }^{11}$ In that case, the power to 'correct the mistake' was used to remove later interests from the register. ${ }^{12}$ This approach to paragraph 2(1)(a) meant that the Court of Appeal was able to re-insert the claimants' leases onto the register. Paragraph 8 limited this power to make changes specifically in relation to questions of priority, so that such changes would be 'for the future only'. Thus, although in Roberto Mac the adjudicator was not required to consider paragraph 8 (the case not involving questions of priority as such), the broad interpretation given in that case to paragraph 2(1)(a) meant that Underhill LJ felt confident that he was able to insert the claimants' leases onto the register, but that when dealing with questions of priority, he was limited as to how far he could go in correcting the mistake. This led the Court of Appeal to hold that it was able to give the mistakenly removed interest, 'the priority which it should have had but for the mistake'. ${ }^{13}$

\footnotetext{
${ }^{6}$ ibid at [96]

${ }^{7}$ Land Registration Act 1925, section 82(2): '(2)The register may be rectified under this section, notwithstanding that the rectification may affect any estates, rights, charges, or interests acquired or protected by registration, or by any entry on the register, or otherwise'.

${ }^{8}$ Argyle Building Society v Hammond (1984) 49 P\&CR 148, 162

${ }^{9} \mathrm{n} 1$ above at [40]

${ }^{10}$ ibid at [65]

${ }^{11}$ Knights Construction (March) Ltd v Roberto Mac Ltd [2011] EWLandRA 2009/1459, [2011] 2 EGLR 124

12 ibid at [131]-[132]

${ }^{13} \mathrm{n} 1$ above at [93]
} 
As to the first question, the court concluded that there was nothing in the case that would constitute exceptional circumstances so as to justify a refusal to rectify the register. ${ }^{14}$ Neither the delay in applying for rectification, ${ }^{15}$ nor the likely inability of the claimants to receive planning permission for conversion of the roofspace constitute sufficient reason to rebut the presumption in favour of rectification in paragraph 3(3) of Sch 4. ${ }^{16}$ This is uncontroversial, and does not merit further discussion here.

\section{Comment}

The interpretation adopted in this case best accords with the language of paragraph 8 . However, the overall consistency in interpretation of Sch 4 can be called into question. There is little attempt in this case, or in any of the previous interpretative cases, to consider how the provisions of Sch 4, Schedule 8 (indemnities) and section 58 (which states that where, but for registration, the registered proprietor would not have held the legal estate, following registration, the estate will be deemed to vest in them) work together in a system where it is intended that the register can be relied upon to provide a situation of certainty for third parties and estate-holders alike. ${ }^{17}$

\section{The wording of paragraph 8}

The essence of the case was the question of what it means to state that priorities can be changed for the future only. There are two possible interpretations. The interpretation adopted by the court means that the claimants' lease ought to be given priority because it was created earlier in time and mistakenly removed. The alternative interpretation, whereby the change of priority is relevant only for future interests (such that the claimants' could not have priority over Gold Harp, but would have priority over interests created after the rectification), would mean, according to Underhill LJ, that the courts would have no power 'correct a mistake' as far as priority is concerned. ${ }^{18}$

The interpretation adopted however, that interests already on the register can be altered, leaves one wondering what 'for the future' adds. It is concluded by the Court of Appeal that this qualification relates, strictly, to the consequences of priority having effect for the future only. Thus, B would not be required to pay damages for trespass or use and occupation or mesne profits for the period of prior to rectification. ${ }^{19}$ To use Underhill LJ's example: 'the Court could have made an order by way of rectification which rendered the leasehold subject to the restrictive covenant for the future, but the beneficiary could not have sued in respect of breaches prior to that date'. ${ }^{20}$ Thus, solely on the wording of paragraph 8 , there is little doubt that the correct interpretation was given to the words used.

\footnotetext{
${ }^{14}$ ibid at [100]

${ }^{15}$ ibid at [101]

${ }^{16}$ ibid at [102]

${ }^{17}$ Law Commission, 'Land Registration for the Twenty-First Century: A Conveyancing Revolution' Report no. 271 (London: HMSO, 2001) at [1.5]

${ }^{18} \mathrm{n} 1$ above at [95]

19 ibid at [96]

${ }^{20}$ ibid
} 
The alternative interpretation, which would result in the claimants' leases being reregistered, but ranking behind Gold Harp's lease, suggested by the author's of Megarry and Wade, ${ }^{21}$ who rank amongst their number the author of the 2002 Act, is not convincing. In support of this interpretation it is argued that the 2002 Act was indeed intended to replicate the 1925 law, but that the relevant case was not Argyle Building Society but Freer $v$ Unwins. ${ }^{22}$ In Argyle Building Society is was held that the court had power to alter priorities so that a first in time priority rule was maintained when re-registering mistakenly de-registered interests. In Freer $v$ Unwins, by contrast, the court held that where, for reasons of a mistake, an interest was not present on the register at the time of the grant of an estate, even if that interest was later registered, it would not be possible to make this binding upon the estate-holder. Thus, for the authors of Megarry and Wade, 'for the future' means: '(i) [i]t affects the proprietor of the registered estate or charge from the time that rectification is ordered; (ii) [i]t affects the priority of any interest affecting the registered estate or charge concerned that is created or arises after rectification is ordered'. ${ }^{23}$ This is an acceptable interpretation of the words 'for the future', but it poses problems for 'alter', since if the priorities can only be altered for the future in the sense used by Megarry and Wade, there is no alteration of priority at all. The priority is determined by the date at which the interest was entered onto the register, not the date at which is ought to have been entered. This would mean that the limitation on 'correcting a mistake' as far as priority is concerned would leave the court without power to alter priority following mistaken de-registration. Such an approach does not sit comfortably with the language of the provision.

Thus, the Court of Appeal was correct in its approach. By treating 'for the future' as referring, strictly, to the consequences of priority, and using what is in effect a first in time rule to determine priority, the wording of paragraph 8 is accounted for.

\section{Interaction with previous authority}

Does the 2002 Act case law support such a conclusion? The position is more complex than the Court of Appeal admits, not least because although the Land Registry supports the conclusion in Knights Construction, ${ }^{24}$ this is not without controversy. ${ }^{25}$ There is extensive discussion elsewhere of this line of case law, ${ }^{26}$ but to conclude that the phrase 'correcting a mistake' should be interpreted broadly is at the very least problematic.

The broad interpretation of 'correcting a mistake' forms an essential background against which the limitation on this power provided for by paragraph 8 operates. There is little doubt that the removal of the lease in this case was a mistake. However, the term 'correcting' must also be interpreted. The broad interpretation in Knights Construction, which suggests that the claimants' leases should, if possible, be given

\footnotetext{
${ }^{21}$ C. Harpum et al, Megarry \& Wade: The Law of Real Property (London: Sweet and Maxwell, 2012)

${ }^{22}$ D. Cavill, Ruoff \& Roper: Registered Conveyancing at [46.017-18]. Freer v Unwins [1976] Ch 288.

${ }^{23}$ n 20 above at [7-136]

${ }^{24}$ S. Brilliant and M. Michell, Practical Guide to Land Registry Adjudication (London: Lexis Nexis 2012) [18-6]

${ }^{25}$ E. Lees, 'Title by registration: rectification, indemnity and mistake and the Land Registration Act 2002' (2013) 76 MLR 62. See also, A. Goymour, 'Mistaken Registrations of Land' (2013) 72 CLJ 617 and S. Cooper, 'Regulating fallibility in registered land titles' (2013) 72 CLJ 341.

26 ibid
} 
priority over Gold Harp's lease, even though at the time of Gold Harp's registration no such leases were present on the register, is not accepted in the existing case law. That Knights Construction represents the correct interpretation of para 2(1)(a) is largely assumed by the Court of Appeal. However, although 'inconclusive', 27 Barclays Bank v Guy takes a much narrower view of the term mistake, reasoning that rights registered on the basis of a mistaken position on the register are not in themselves mistakes. By way of example, if $\mathrm{A}$ is mistakenly removed from the register as freehold proprietor in favour of $\mathrm{B}$, and $\mathrm{B}$ grants a mortgage to $\mathrm{C}, \mathrm{C}$ 's mortgage is not, according to Guy, in itself a mistake. ${ }^{28}$ This narrow approach is supported by Odogwu $v$ Vastguide ${ }^{29}$ where Rattee J reasoned that 'correcting a mistake' does not necessarily extend to correcting the consequences of a mistake, and by Stewart v Lancashire Mortgage Corp. ${ }^{30}$

There are, therefore, essentially three interpretations of the relevant provisions present in the case law. No one case has examined all these options simultaneously and there is little guidance as to they interact.

(1) Firstly, the court could rely on a broad interpretation of the term mistake. There is a clear mistake in the removal of the claimants' leases. What is less clear from is whether the registration of Gold Harp's lease is a mistake. ${ }^{31}$ If such an approach were taken, then Gold Harp's lease could also be rectified off the register, and then re-registered, if appropriate, subsequent to the claimants' leases. In such a case, the claimants would have priority over Gold Harp. ${ }^{32}$

(2) Secondly, the court could simply rely on a broad interpretation of 'correcting', so that correcting the mistake of removing the claimants' leases would involve ensuring priority over Gold Harp. ${ }^{33}$ Thus, although the registration of Gold Harp was not in itself a mistake, the priority of their lease could be altered because in order to fully correct the mistake of removing the claimants' leases, their leases would need to have priority over Gold Harp. This approach sees paragraph 8 as a power limiting, rather than power conferring provision.

(3) Finally, the court could rely on paragraph 8, seeing it as a power conferring provision, and use the explicit power to alter priorities for the future as they saw fit.

These different approaches all appear at different points within the case law. The case law is not in direct conflict since very often the courts focus on different provisions, but nor does it demonstrate a consistency of approach which produces a degree of predictability and certainty for those relying on the register. It is perhaps apparent that the judiciary are steering against a strong conception of the conclusivity of the register. ${ }^{34}$ Their approach is demonstrating that off-register investigations will still be

\footnotetext{
${ }^{27} \mathrm{n} 1$ above at [68]

${ }^{28}$ Barclays Bank v Guy (No 1) [2008] EWCA Civ 452, [19]

${ }^{29}$ Ogodwu v Vastguide [2009] EWHC 3565 (Ch), [58].

${ }^{30}$ Stewart v Lancashire Mortgage Corp Ltd [2010] EWLandRA 2009_0086, [65]

${ }^{31}$ Barclays Bank v Guy [2008] 2 EGLR 74; Barclays Bank v Guy (No 1); Barclays Bank v Guy (No 2)

[2011] 1 WLR 681 and Stewart v Lancashire Mortgage Corp Ltd

32 ibid

${ }^{33}$ Ajibade v Bank of Scotland \& Endeavour Personal Finance Ltd [2008] EWLandRA 2006_0174 but see Stewart $v$ Lancashire Mortgage Corp Ltd

${ }^{34}$ S. Gardner, 'The Land Registration Act 2002 - the Show on the Road' (2014) 77 MLR 763, 772; A. Goymour, n 24 above 646-647.
} 
required. However, there is doubt, in each case, as to what approach the court will use to reach this conclusion, and therefore, for the parties, doubt as to what arguments they must bring with regards to the courts discretion, the relevant provisions, and the case law to cite.

It can be hoped that this more authoritative statement of the law would be taken to settle the matter. Even if the solution reached is not universally popular, it is at least a clear answer to the problem of the operation of paragraph 8. It is unlikely that certainty will be achieved however, since there are still too many different options for a court to take which are not ruled out by the decision in this case. For example, the trust solution in Fitzwilliam $v$ Richall ${ }^{35}$ and its substantial modification in Swift $1^{\text {st }} v$ Chief Land Registrar ${ }^{36}$ and the 'correcting the mistake' approach which does not call upon paragraph 8, are not in direct conflict with Gold Harp. Nor, however, does the possibility of such a range of options provide for a coherent system as a whole.

\section{The result for the conclusivity of the register}

This range of options produces a problem for the conclusivity of the register: not one of strength, but, more importantly, a problem of consistency.

One aspect of this relates to the reliance placed on the register and the question as to what is meant by 'the priority which it should have had' but for the mistake. The language of this statement misrepresents the issue, for in many cases it is not that an interest belonging to A would have priority over the interest belonging to B but for the mistake, but rather that B's interest may never have been created but for the mistake. Underhill LJ's language underplays the reliance that B may have placed on the register when acquiring their interest. It also underplays the extent to which later interest holders rely on the absence of an interest on the register, just as much as a current interest holder relies on the fact of their interest being registered. The guarantee provided by the register is two-way: if there is registration, the legal estate is guaranteed - if there is no registration, the legal estate cannot exist and, for the most part, only observable actual occupation will result in a transferee for consideration being bound.

The facts of this case - the cunning of Mr Ralph - obscures the fact that once again we are dealing with the question as to how safe it is to rely on the register. Again, it raises the question - who loses out: the old registered proprietor, or the new registered proprietor? Of course, an indemnity may come to the rescue of the 'losing' party, ${ }^{37}$ but having the property right is not the same as having money. In this sense, it raises the same questions as did Fitzwilliam v Richall, Barclays Bank $v$ Guy, and Swift $1^{\text {st }} v$ Chief Land Registrar, albeit in relation to a different provision.

If the outcome of this case is considered in general terms, it has the consequence of further undermining the possibility of confidence in the register since it confirms the tenor of much of the earlier case law that the register cannot be treated as conclusive

\footnotetext{
${ }^{35}$ Fitzwilliam $v$ Richall [2013] EWHC $86(\mathrm{Ch})$. The 'trust solution' provides that where a transfer of title to an estate is forged, although the new registered proprietor will have good legal title as a result of section 58, they will hold that title on trust for the original proprietor.

${ }^{36}$ Swift 1st $v$ Chief Land Registrar [2014] All E.R. (D) 12 (Feb)

${ }^{37}$ Land Registration Act 2002, schedule 8
} 
as to either the existence, or the lack of existence, of an estate in land which can bind a future transferee. Although the register has never claimed to be conclusive with regards to interests in land, it is designed to be conclusive as to the presence or absence of legal estates in land (in that, it confers validity onto legal estates in land, and means that there can be no legal estate in land without registration) - freehold, leasehold, or the charge in its form of leasehold estate - and so by indicating that an earlier, but unregistered, leasehold estate can be binding upon the future transferee, confidence is necessarily undermined. Although the register can be altered, it is designed to represent a conclusive picture of such estates in land as exist at any particular time. Undermining this conclusivity may be acceptable, even if this was not what the drafters of the 2002 Act sought to achieve, since it protects those who have, through no fault of their own, lost their rights. What is critical however is that those who rely on the register are able to assess the extent of the risk they adopt when sorelying. The current multitude of solutions to the 'who should lose out' problem means that such an assessment is nearby impossible.

\section{The alternative}

There is however, an alternative approach, one which makes sense both of the provisions in Sch 4, and which accords with the general principles of registration embodied in the Act, giving a greater degree of protection to purchasers. Underhill LJ suggests, but ultimately does not go onto to fully consider, such an alternative. ${ }^{38}$ This approach relies on the fact Gold Harp was not a transferee for value such that section 28 (which explains that a first in time priority rules applies to transferees not for value), not section 29 (which establishes the priority rule for transferees for value), determines the priority of their lease over pre-existing interests. ${ }^{39}$ Gold Harp, being not a purchaser, would be bound by any interest which bound the estate immediately prior to the disposition, such as the claimants' right to rectify the register. This would be so notwithstanding the fact that no mention was made of this right on the register, and that the claimants were not in actual occupation, precisely because this is a section 28 , not a section 29 case.

The judge himself was 'not wholly comfortable' ${ }^{40}$ with this analysis. Indeed, the reliance on the fact of the claimants' leases being prior in time indeed does pose some difficulties. At the time of Gold Harp's registration, there was arguably no prior in time lease. What there definitely was, however, was a prior in time right to rectify. ${ }^{41}$ It is this interest which should determine the priorities as between Gold Harp and the claimants. In section 29 cases (i.e. transfers for value), if this approach were followed, what would matter would be whether the claimant was protecting their right to rectify the register, either by entering a notice of it, or by being in actual occupation, at the time of the relevant disposition. Such an approach does not appear explicitly within the statutory provisions, but nor is it precluded by them.

How does this alternative approach interact with the wording of paragraph 8 ? The provision states that the court may 'change for the future the priority'. This would be a useful power if, thanks to section 28 or 29 , the more recent right holder was bound

\footnotetext{
${ }^{38} \mathrm{n} 1$ above at [34]

${ }^{39}$ ibid

40 ibid

${ }^{41}$ Proudlove v Wood [2011] PLSCS 206
} 
by the right to rectify, but it would make no sense for them to be bound by the substantive right to which that rectification related, in this case Gold Harp's lease, since in such a circumstance the later registered proprietor would already be bound by that interest. Where the right which bound them was merely the right to rectify, whilst the court would of course be entitled to rectify against them and they would normally rank below the claimant's right, the court would be able to change the priority of the substantive right and the newer interest for future purposes.

It seems at first glance that such a scheme would add additional qualifications to the process of rectification than appears from Sch 4, limiting the circumstances in which the register can be rectified in a way not indicated in the schedule itself. But this conclusion is false. Sch 4 is concerned with the fate of one registered estate. Sch 4 tells us when estates can be taken off the register or put back on the register when it has been mistakenly removed. The drafting of Sch 4 means that it is unclear from the schedule itself what the consequences of removing or registering such an interest are. Schedule 4 simply explains when such a removal or registration is possible. Thus, thanks to the failure to define 'correct' or 'mistake', it tells us little about what powers the provision in paragraph 8 is intended to limit. Without knowing this, it is difficult to explain what rectification for the future only in terms of priority means. Reliance on the priority provisions in section 28 and 29, and the right to rectify the register as a substantive property right, may well provide a better solution to that problem. Furthermore, it would provide a means by which the transferee of rights could assess the level of risk they were undertaking with regards to off-register interests, and would, in accordance with the general principles of the 2002 Act, provide a greater degree of protection to purchasers than to gratuitous transferees. Under this approach schedule 4 simply explains when the correction of mistakes is possible. Sections 28 and 29 explain the consequences of this correction in terms of priority.

The system in Schedule 4 would then operate as follows. The first question would be whether the registration or de-registration of a right on the register was a mistake. If it was a mistake, the next question would be whether there was a registered proprietor in possession who would lose out were rectification to take place. If so, the court would need to assess whether such a proprietor contributed to the mistake, and whether there were any other reasons why it would be unjust not to rectify. In effect, there is a presumption against rectification in such circumstances. If there was no proprietor in possession, the court would have to assess whether there were exceptional circumstances which would justify not rectifying the register. In this case there is effectively a presumption in favour of rectification.

Once these decisions had been made, the court must turn to the other estates, if any, present on the register, to determine firstly whether the presence of those interests is directly related to the original mistake, e.g. the registration of a charge against a wrongly-registered estate. In such circumstances, if the approach in Knights Construction is followed, as the Court of Appeal here indicates that it should be, such charges should also be rectified off the register. However, there may still remain on the register interests which are not in fact caused by the original mistake, and which therefore cannot be considered 'consequences' of that mistake. This would include the grant of a lease by a freeholder where there is no mistaken registration, as here. In these circumstances, the Court must decide whether the power in paragraph 8 allows them to alter the ordering of interests on the register so as to ensure priority for the 
rectified estate. Whether they should do this will be determined by whether or not such an estate is bound by the right to rectify the register according to the normal priority rules under sections 28 and 29 . This would not produce certainty in all cases, and is primarily applicable where an estate is mistakenly removed from the register, rather than where an interest is mistakenly added (albeit that most rectification cases will in fact involve both). However, such an approach ought to prove more consistent than that currently in operation and, crucially, it gives a strong degree of protection to purchasers of estates in land.

\section{Conclusion}

Whatever approach to paragraph 8 , sch 4 , is taken, the language is not necessarily conclusive. Nor, in this author's view, is it clear from the Law Commission report precisely what this power related to, and the earlier case law too is unhelpfully unclear in this respect. The interpretation adopted by Underhill LJ is a perfectly sensible one. The 'for the future' aspect relates to the ordering of the rights on the register and therefore as against each other (if required): the 'past' aspects relates to questions such as mesne profits, and trespass damages, where necessary. However, this interpretation does not sit entirely comfortably with existing decisions in that it takes an approach to questions of 'correcting a mistake' which diverges from Stewart $v$ Lancashire, Ogodwu v Vastguide and Barclays Bank v Guy. The decision in Gold Harp is however the most authoritative on this point - it is the only Court of Appeal decision with the authority of precedent (Barclays Bank $v$ Guy being a permission to appeal) - and therefore represents the best indication that we have as to the conclusivity of the register, its relationship with the rectification and indemnity provisions, and for the status of registered interests.

The impending Law Commission consideration of the priorities and guarantee of title provisions within the 2002 Act is to be greatly welcomed, not because sweeping substantive changes to the law are necessarily required, but because wholesale clarification, on a comprehensive and not piecemeal basis, is needed. ${ }^{42}$ The current case law has not provided such an opportunity since each case considers in isolation specific provisions, without considering the operation of the system as a whole. Such a consideration may rely on the alternative approach suggested by Underhill LJ, and explored here. It is important however that whatever decision is made as to the desired conclusivity of the register, as to the strength of guarantee provided by the register, and as to the scope of the court's and Land Registry's powers to rectify the register and alter the priority of interests and estates emerging from that register, that the approach is consistent. The Law Commission may have hoped for a register which allowed for the minimum of off-register investigations, but that is not what has emerged. What we should have has been discussed elsewhere, but whatever we should have, it should be consistent and predictable, and by adding another different mechanism by which priority of estates is regulated, uncertainty abounds.

${ }^{42}$ Law Commission, http://lawcommission.justice.gov.uk/areas/land-registration.htm 